\title{
ANALISIS TERJADINYA KARIES GIGI BERDASARKAN PEMERIKSAAN KADAR MUC7 DAN ENZIM GLUKOSILTRANSFERASE (GTF) SALIVA PADA ANAK-ANAKKARYAWAN PTPN VIII YANG BERUMUR 12-13 TAHUN
}

\author{
Dental Caries Analysis Based On Salivary \\ Examination Of Muc7 Levels and Enzyme \\ Glucosyltransferase (gtf) In 12-13 Years Old Children PTPN VIII Employees
}

Sjazili S. Muhibat

Universitas Padjadjaran

email korespondensi: drgsjazili@yahoo.com

\begin{abstract}
Abstrak
Karies gigi merupakan penyakit infeksi multifaktorial, faktor etiologi tersebut saling berkaitan satu sama lainnya dan digambarkan sebagai empat lingkaran yang saling berimpitan satu sama lainnya. Protein saliva MUC7 yang terdapat dalam saliva berperan penting dalam melindungi jaringan lunak dan keras rongga mulut dari infeksi bakteri patogen. Tujuan penelitian ini untuk mengetahui kaitan antara MUC7 dan glukosiltransferase dengan karies gigi, yang dapat menimbulkan dugaan bahwa MUC7 dan glukosiltransferase berperan penting terjadi karies gigi. Motode penelitian ini bersifat cross sectional study di lapangan dan laboratorium. Sampel penelitian ini adalah 138 orang anak karyawan PTPN VIII Pengalengan usia 12-13 tahun. Pada penelitian ini digunakan analisis chi kuadrat, korelasi rank Spearman, analisis regresi logistik ganda dan kurva ROC. Hasil penelitian terdapat korelasi yang signifikan antara MUC7 dengan karies gigi, nilai koeffisien korelasi 0,209* dengan p 0,014, dan tidak terdapat korelasi yang signifikan antara glukosiltransferase dengan karies gigi. Hasil perhitungan dengan regresi logistic ganda diperoleh hubungan yang signifikan antara MUC7, glukosiltransferase (GTF) dengan karies gigi. Hasil kurva ROC diperoleh bahwa kadar MUC7 $\leq 604,02 \mathrm{ng} / \mathrm{ml}$ akan berrisiko terjadinya karies gigi 2,085 kali bila dibandingkan dengan kadar MUC7 $>604,02 . \mathrm{ng} / \mathrm{ml}$. Sedangkan kadar Gtf $\leq 5,247 \mathrm{ng} / \mathrm{ml}$ juga berrisiko terjadi karies gigi sebesar 2,273 kali dibandingkan dengan kadar Gtf $>5,247 \mathrm{ng} / \mathrm{ml}$. Simpulan penelitian ini adanya korelasi yang signifikan antara MUC7, GTF dengan karies gigi. Menunjukkan pula bahwa rendahnya kadar MUC7 dan glukosiltrans ferase (GTF) lebih berrisiko terhadap terjadinya karies gigi.
\end{abstract}

Kata kunci; MUC7, glukosiltransferase (GTF), karies gigi

\section{Abstract}

Dental caries is a multifactorial infectious disease, which the etiologic factors are related each other and are shown as four interlocking circles coincide with each other. MUC7 salivary proteins plays an important role in protecting the hard and soft tissues of the oral cavity from bacterial pathogen infection. The aim of this research was to each other between MUC7 and glucosyltransferase to dental caries, which can give rise to allegations that the MUC7 and glucosyltransferase plays an important role occur of dental caries. Method of this study is a cross sectional in the field and laboratory. The samples were 138 the children of employees of PTPN VIII Pengalengan 12-13 years old. Analyses of this study are X2, Spearman's rank test, multiple regression, logistic regression, and ROC curve. The results there was a significant correlation between MUC7 with dental caries, the value of the correlation coefficient $0.209^{*}$ and $p=0.014$, and there was no significant correlation between the glucosyltransferase to dental caries. Calculation of logistic regression obtained significant relationship between MUC7, glucosyltransferase (GTF) with dental caries. The result of ROC curve was obtained that MUC7 levels $\leq 604.02 \mathrm{ng} / \mathrm{ml}$ will be at risk 2,085 times dental caries levels when compared with MUC7> $604.02 \mathrm{ng} / \mathrm{ml}$. While the GTF levels $\leq 5,247 \mathrm{ng} / \mathrm{m} /$ are also at risk of dental caries occurs 2,273 times compared to the GTF levels $>5,247 \mathrm{ng} / \mathrm{ml}$. The conclusions of this study are significant correlation between MUC7, GTF to dental caries. Also showed that low level of MUC7 and glucosyltransferase (GTF) is more at risk for dental caries.

Key word: MUC7, glucosyltransferase, dental caries.

\section{PENDAHULUAN}

Karies Gigi merupakan penyakit infeksi multifaktorial yang bersifat kronis mengakibatkan kerusakan jaringan keras gigi sehingga menciptakan rongga atau lubang. Kerusakan tersebut oleh koloni mikroflora mulut dipermukaan gigi yang menfermentasi karbohidrat menghasilkan asam. Terdapat tiga faktor utama yang menimbulkan karies tersebut yaitu host (gigi dan saliva), mikroflora, dan substrat atau karboihidrat, serta faktor waktu yang harus dipertimbangkan.

Program kebersihan gigi dan mulut telah sering dilakukan, begitu pula anjuran untuk tidak mengkonsumsi makanan yang banyak mengandung gula. Akan tetapi tetap saja karies gigi meningkat, Dalam hal ini ada kemungkinan faktor lain yang belum terungkap dalam kandungan saliva.
Saliva terdiri lebih dari $99 \%$ air dan zat padat terlarut kurang dari 1\%, terutama protein, garam/elektrolit, lendir, glikoprotein, enzim, dan senyawa antibakteri seperti sekresi SIgA dan lisozim. Garam-garam yang terdapat di saliva terutama natrium, kalium, klorida, bikarbonat, kalsium, fosfat dan magnesium. Sedangkan kandungan mikroorganisme mulut banyak sekali antaranya Streptokokus mutan, S. sobrinus, $S$. sanguinis, S. mitis, dan S. Oralis, Actinomyces viscosus dan Actinomyces naeslundii. Streptokokus mutan sendiri telah hadir sejak masih bayi sebelum erupsi gigi.

Komponen saliva berperan penting dalam proses adhesi bakteri membentuk "salivary acquired bacterial pellicle" biofilm, atau pelikel, pada permukaan gigi. Pelikel adalah glikoprotein yang berasal dari saliva dan menempel pada permukaan email gigi, berfungsi 
sebagai nutrisi untuk pertumbuhan mikro organisme plak, mencegah deposisi terus menerus kalsium fosfat saliva.

Fungsi saliva menghambat pertumbuhan organisme mulut oleh faktor pertahanan nonspesifik antara lain lisozim, laktoferin serta histatins yang bersifat bakterisida dan fungisida, serta adanya faktor pertahanan spesifik (misalnya immunoglobulin, terutama $\operatorname{lgA}$ ), sedangkam kandungan garam-garam menjaga $\mathrm{pH}$ saliva menjadi normal (buffer). Hal tersebut di atas telah sering diteliti kaitannya dengan karies gigi terutama mempelajari saliva antara lain dengan laju aliran, sifat stimulasi, lama stimulasi, komposisi plasma, waktu sampel dikumpul, Streptokokkus mutan dan $\mathrm{pH}$ saliva, yang telah ditetap sebagai pemeriksaan rutin dan telah ditentukan sebagai faktor resiko karies. Sedangkan MUC7 yang merupakan kandungan saliva dan glusiltransferase (GTF) merupakan antigen permukaan dari Streptokokus mutan yang belum termasuk dalam pemeriksaan tersebut masih harus dilakukan penelitian.

Oligosakarida terutama glikoprotein berkorelasi positif dengan terjadinya karies. Glikoprotein mukosa, yang berupa musin, berasal dari sel asinar, dengan kandungan 40 persen karbohidrat. Terdapat 2 musin utama yaitu MG1 dan Mg2, yang saat ini dilambangkan dengan MUC5B dan MUC7. MUC5B diproduksi sel mukosa kelenjar submandibula dan sublingual, berat molekul $1000 \mathrm{kDa}$, sehingga sering dikatakan juga sebagai musin dengan berat molekul tinggi. Sedangkan MUC7 diproduksi sel mukosa dan serosa kelenjar saliva kecuali kelenjar parotis, terdiri atas rantai peptide tunggal dengan berat molekul $150 \mathrm{kDa}$, sehingga dikatakan juga sebagai musin dengan berat molekul rendah. MUC7 hanya terdapat di saliva yang bisa mengaglutinasi Streptokokus mutan sehingga dapat menempel pada pelikel, dan MUC7 juga sebagai bahan nutrisi mikroba. Sedangkan MUC5B sendiri merupakan musin yang membentuk pelikel. Terdapat pendapat yang berbeda dan bertentangan diantara para peneliti mengenai hubungan antara MUC7 dengan karies gigi.

Streptokokus mutan telah diidentifikasi mengandung enzim glukosiltrans ferase pada permukaan dinding selnya. Enzim glucosiltransferase dapat merubah sukrosa menjadi glukan (dekstran). Glukan (dekstran) ini bersifat lengket dan mengeratkan sehingga terjadi penempelan Streptokokus mutan satu sama lainnya yang membentuk koloni yang menempel pada gigi.

Masih terdapat pendapat yang berbeda dan bertentangan diantara para peneliti mengenai hubungan antara glukosiltransferase dengan caries gigi. Mengingat masih adanya hasil penelitian yang bertentangan dari penelitian, mengenai hubungan karies dengan MUC7 dan glukosiltransferasi mendorong penelitian penulis untuk melakukan penelitian mengenai terjadinya karies gigi hubungannya kadar MUC7 dan enzim Glukosil-transferase pada saliva pada anak karyawan PTPN VIII di Pengalengan yang berumur 12-13 tahun.

Berdasarkan hal tesebut, dilakukan penelitian ini dengan tujuan ingin melihat.

1. Apakah tingginya kadar MUC7 saliva merupakan faktor risiko terjadinya karies gigi pada anak-anak usia 12 - 13 tahun
2. Apakah tingginya kadar enzim glukosiltransferase (GTF) saliva merupakan faktor risiko terjadinya karies gigi pada anak-anak usia 12-13 tahun

3. Apakah terdapat hubungan antara kadar MUC7, dengan kadar enzim glukosiltrans ferase (GTF) dalam saliva dan saling berkaitan dengan terjadinya karies gigi.

\section{METODE}

Rancangan penelitian yang digunakan pada penelitian ini adalah penelitian cross sectional, dan tidak dilakukan pengulangan pengukuran. Subjek penelitian ini adalah siswa usia 12-13 tahun di SMPN 2 Pengalengan, merupakan anak karyawan PTPN VIII Pengalengan yang bertempat tinggal di perkebunan tersebut yang memenuhi criteria inklusi dan eksklusi serta bersedia mengikuti penelitian dengan mengisi lembaran persetujuan (informed consent) kriteria inklusi pada penelitian ini adalah siswa usia $12-13$ tahun, berdomisili di perkebunan Pengalengan paling sedikit 1 tahun, kondisi yang sehat, dan laki-laki maupun wanita. Kriteria eksklusi adalah siswa yang tidak komunikatif dan kooperatif menurut peneliti dan didiagnosa secara klinis menderita penyakit periodontal atau penyakit lain selama penelitian.

Pemilihan subjek penelitian dilakukan secara stratifikasi random sampling dengan ukuran sampel seimbang. Sebelumnya, orangtua/wali penderita telah diberi penjelasan dan mereka setuju ikut dalam penelitian (informed consent). Penelitian ini telah mendapat persetujuan dari Komite Etik Penelitian Kesehatan Fakultas Kedokteran Universitas Padjadjaran Bandung-RSUP Dr. Hasan Sadikin Bandung dengan nomor: 153/UN6.C2.1.2/KEPK/PN/2012.

Pengumpulan data dilakukan dengan cara; pertama subjek mengisi kuesioner kemudian dilakuikan pemeriksaan intra oral untuk mendapatkan perbedaan karies gigi. Setelah selesai pemeriksaan intra oral, maka subjek diambil salivanya dan ditampung pada wadah yang telah disediakan. Pengabilan saliva ini guna menganalisis kadar MUC7, dan GTF kemudian analisis dengan metode enzyme-linked immunosorbent assay (ELISA) di laboratorium.

Analisis deskriptif dilakukan hitung besaran jumlah dan persentase serta menghitung ukuran statistik lainnya yaitu rata-rata, SD, median dan rentang. Sedangkan untuk analisis analitik digunakan uji Chi kuadrat untuk menguji perbedaan karakteristik data kategorik. Uji Mann Whitney untuk membandingkan perbedaan median dari kedua kelompok. Uji analisis korelasi data numerik (kadar GTF dan MUC7) dengan kejadian karies digunakan uji korelasi Point Beserial.

Uji analisis perbedaan kadar GTF dan kadar MUC7 berdasarkan kategori plak (rendah, sedang, dan tinggi) dengan menggunakan Kruskal-Wallis, sedangkan mengukur kekuatan hubungan dengan menggunakan korelasi rank Spearman. Menentukan Cut Off Point kadar MUC7 dan kadar GTF yang dapat dipakai sebagai prediktor harus digunakan kurva ROC (Receiver operating characteristic) Begitu pula untuk menganalisis pengaruh simultan kadar MUC7 dan kadar GTF terhadap kejadian karies gigi digunakan analisis regresi logistik ganda. Kemaknaan hasil uji berdasarkan nilai $p<0,05$. 


\section{HASILDAN PEMBAHASAN}

Penelitian tentang karies dengan memeriksa kadar MUC7 dan GTF pada saliva telah dilakukan terhadap 138 anak karyawan yang berusia $12-13$ tahun yang menetap di perkebunan PTPN VIII Pengalengan desa Banjar Sari. Subjek terdiri dari 69 berusia 12 tahun dan 69 yang berusia 13 tahun, dan terhadap semua subjek dilakukan pencatatan data dasar dengan kuesioner, sedangkan untuk GTF dan MUC7 dengan saliva.

Hasil pemeriksaan ditemukan 108 anak menderita karies gigi dan berdasarkan angka ini diperoleh angka prevalen 78,3 persen, dengan $95 \%$ konfiden interval antara 71,4 - 85,2 \%. Hasil pemeriksaan kategori plak ditemukan kategori plak rendah 19 anak (13,8 persen), sedang 57 anak (41,3 persen), dan tinggi 62 anak (44,9 persen).

Karies yang dialami oleh subjek penelitian adalah karies oklusal dan hampir tidak ada yang mengalami karies bukal maupun karies servikal. Oleh karena itu, maka dilakukan perhitungan indek DMFT. Nilai tersebut didapatkan dari penjumlahan unsur $D+M+F$ dibagi dengan yang diperiksa. Unsur karies (D), unsur gigi hilang karena karies (M), dan unsure gigi yang ditambal (F).

Hasil perhitungan Indeks DMFT pada anak karyawan PTPN VIII Pengalengan usia $12-13$ tahun terlihat pada Tabel 1

Tabel 1 Indek DMFT

anak karyawan PTPN VIII usia 12 - 13 tahun

\begin{tabular}{lll}
\hline Kategori & Jumlah & Persentase \\
\hline D & 391 & 94,22 \\
M & 24 & 5,78 \\
F & 0 & 0 \\
\hline Total D+M+F & 415 & 100 \\
\hline
\end{tabular}

Hasil pemeriksaan ditemukan DMFT siswa-siswi sebesar 3,007. Nilai tersebut didapatkan dari penjumlahan unsur $D+M+F$ dibagi dengan yang diperiksa. Unsur karies (D), unsur gigi hilang karena karies (M), dan unsure gigi yang ditambal (F).

$$
\text { DMFT }=\frac{\text { Total } D+M+F}{\text { Jumlah yang diperiksa }}
$$

Kriteria tinggi rendahnya indeks DMF-T yang ditetapkan WHO.

$$
\begin{array}{lll}
<1,2=\text { sangat rendah } & 1,2-2,6=\text { rendah } \\
2,7-4,4=\text { sedang } & >4,4=\text { tinggi }
\end{array}
$$

Berarti siswa di SMPN 2 Pengalengan rata2 terdapat 3 gigi yang berlubang, pernah dicabut serta pernah ditambal dengan kategori sedang.

Karakteristik jenis kelamin subjek memperlihatkan bahwa karakteristik jenis kelamin yang mengalami karies dan non karies. Subjek siswi non karies terdapat 12,32 persen, sedangkan siswi yang mengalami karies sebanyak 50,72 persen. Sebaliknya siswa non karies sejumlah 9,42 persen, dan berkaries sebanyak 27,54 persen. Analisis statistik dengan menggunakan uji Chi Kuadrat, maka didapatkan bahwa antara karies gigi dengan jenis kelamin tidak terjadi hubungan dengan nilai p 0,413. (Tabel 2)

Tabel 2, tersebut juga memperlihatkan berusia 12 tahun dan 13 tahun telah diperolah masing-masing 50 persen yaitu 69 subjek usia 12 tahun dan 69 yang berusia 13 tahun. Usia 12 tahun non karies terdapat 11,59 persen, sedangkan berkaries sebanyak 38,41 persen. Adapun pada usia 13 tahun non karies relatif lebih rendah dari usia 12 tahun yaitu 10,14 persen, akan tetapi yang berkaries sedikit lebih tinggi yaitu 39,86 persen. Dilakukan uji Chi Kuadrat, diperoleh hasil tidak terdapat hubungan antara usia dengan kejadian karies gigi dengan $p=0,680$.

Tabel 2 Kejadian karies berdasarkan karakteristik subjek

\begin{tabular}{|l|l|l|l|}
\hline Karakteristik & \multicolumn{2}{|l|}{ Kejadian Karies Gigi } & Nilai \\
\cline { 2 - 3 } & $\begin{array}{l}\text { Berkaries }(+) \\
\mathrm{n}=108\end{array}$ & $\begin{array}{l}\text { Non Karies }(-) \\
\mathrm{n}=30\end{array}$ & \\
\hline Jenis Kelamin & & 13 & 0,413 \\
Laki- laki & 38 & 17 & \\
wanita & 70 & 16 & 0,680 \\
\hline Usia Siswa & & 14 & \\
12 tahun & 53 & & \\
13 tahun & 55 & & \\
\hline
\end{tabular}

Ket ; Berdasarkan uji Chi Kuadrat

Karakteristik prilaku subjek dalam memelihara kesehatan gigi pada penelitian ini disajikan berupa kebiasaan menyikat gigi, jumlah menyikat gigi dalam satu hari, cara subjek menyikat gigi serta bagaimana subjek memilih sikat gigi. Pada Tabel 3 disajikan gambaran prilaku subjek dalam memelihara kesehatan gigi dan mulut.

\begin{tabular}{|c|c|c|c|}
\hline \multirow[t]{2}{*}{ Karakteristik } & \multicolumn{2}{|c|}{ Kejadian karies gigi } & \multirow{2}{*}{$\begin{array}{l}\text { Nilai } \\
\left.\mathrm{p}^{*}\right)\end{array}$} \\
\hline & $\begin{array}{l}\text { Berkaries }(+) \\
n=108\end{array}$ & Non Karies $(-) n=30$ & \\
\hline Kebiasaan menyikat Gigi & & & 0,735 \\
\hline Saat mandi & $45 \quad 32,61 \%$ & & \\
\hline Setelah sarapan pagi & $\begin{array}{ll}45,53 \% \\
9\end{array}$ & $\begin{array}{ll}12 & 0,710 \\
1 & 0,7 \%\end{array}$ & \\
\hline Sesudah makan & $25 \quad 18,12 \%$ & $9 \quad 6,53 \%$ & \\
\hline Sebelum tidur & $29 \quad 21.01 \%$ & $8 \quad 5,8 \%$ & \\
\hline Banyak menyikat gigi sehari & & & 0,120 \\
\hline 1 kali & 1 & & \\
\hline 2 kali & 61 & 11 & \\
\hline 3 kali & 45 & 18 & \\
\hline Cara menyikat gigi & & & 0,267 \\
\hline Umum dilakukan & 42 & 14 & \\
\hline Gari gusi ke gigi & 24 & 2 & \\
\hline Bulu sikat diputarkan & 21 & 8 & \\
\hline Dari gusi digetarkan kegigi & 20 & 6 & \\
\hline Bentuk sikat gigi & & & 0,141 \\
\hline Bulu dan warna sikat yang unik & 19 & 2 & \\
\hline Merek terpecaya/mahal & 89 & 28 & \\
\hline
\end{tabular}

Tabel 3 Gambaran Prilaku subjek terhadap Pemeliharaan kesehatan gigi

Keterangan *) Berdasarkan Uji Chi Kuadrat.

Analisis statistik dengan menggunakan uji Chi Kuadrat, diperoleh bahwa antara karies gigi dengan kebiasaan menyikat gigi juga tidak memperlihatkan hubungan tercermin dengan nilai $p$ 0,735 serta antara karies gigi dengan jumlah subjek menyikat gigi dalam sehari diperoleh hasil nilai $p=0,120$. Demukian pula cara siswa menyikat gigi diperoleh nilai $p=0,267$ serta cara memilih sikat gigi, juga tidak memperlihatkan hubungan dengan nilai $p=0,141$. Hasil Tabel 2 dan Tabel 3 tampak gambaran karakteristik antara kelompok tersebut tidak terdapat perbedaan yang bermakna $p>0,05$. Berdasarkan homogenitas subjek, maka layak dapat diperbandingkan.

Perbandingan Kadar MUC7 dan GTF berdasarkan Kejadian Karies Gigi, yang didapatkan dari subjek yang berkaries 108 siswa dan non karies 30 siswa diperlihatkan pada Tabel 4.4. 
Tabel 4 Perbandingan Kadar MUC7 dan GTF berdasarkan Kejadian Karies Gigi

\begin{tabular}{|c|c|c|c|c|}
\hline \multirow{2}{*}{$\begin{array}{l}\text { Variabel } \\
\end{array}$} & \multicolumn{3}{|l|}{ Karies Gigi } & \multirow{2}{*}{$\begin{array}{l}\text { Nilai } \\
\mathrm{p}^{* 1}\end{array}$} \\
\hline & $+(n=108)$ & $-(=30)$ & Gab $(n=138)$ & \\
\hline $\begin{array}{ll}\text { GTF } \\
\end{array}$ & & & & 0,237 \\
\hline Mean (SD) & $4,239(3,133)$ & $5,067(3,304)$ & $4,505(3,172)$ & \\
\hline Median & 3,918 & 4,969 & & \\
\hline Rentang & $0,020-14,533$ & $0,251-10,600$ & $0.20-14,533$ & \\
\hline MUC7 & & & & 0,242 \\
\hline Mean (SD) & $758,364(444,291)$ & $791,954(379,202)$ & $765,666(429,885)$ & \\
\hline Median & 604,024 & 662,935 & 617,464 & \\
\hline Rentang & $244,364-2316,859$ & $293,161-2316,859$ & $244,364 \quad 2316,859$ & \\
\hline
\end{tabular}

Ket : *) Berdasarkan Uji Mann-Whitney

Hasil Perbandingan GTF antara subjek yang berkaries dengan non karies didapatkan median subjek yang berkaries didapatkan nilai 3,918 dan yang non karies 4,969 dengan $p=0,237$. Hasil ini dapat dikatakan bahwa tidak ada berbedaan GTF antara subjek yang berkaries dengan yang non karies. Begitu pula halnya dengan MUC7 berdasarkan subjek berkaries dan non karies, maka diperoleh median subjek berkaries 604,024 dan yang non karies 662,935 dengan $p=0,242$. Hasil ini juga menunjukkan bahwa kadar MUC7 tidak terdapat perbedaan antara subjek yang berkaries dengan subjeknon karies.

Korelasi antara karies dengan GTF dan Muc7, pengukuran kuatnya korelasi, digunakan korelasi point biserial, maka diperoleh hasil korelasi GTF dengan Karies gigi $r_{p b i}=-0,094, p=0,273$ dan korelasi MUC 7 dengan karies gigi $r p b i=-0,101$, dengan $p=0,240$. Hasil tersebut ternyata tidak terdapat korelasi antara kejadian karies gigi dengan GTF dan MUC7.

Menentukan Cut Off Point kadar MUC7 dan kadar GTF yang dapat dipakai sebagai prediktor digunakan Kurva ROC (Receiver operating characteristic). Hasil yang diperoleh dari kurva ROC terligat dari grafik berikut.

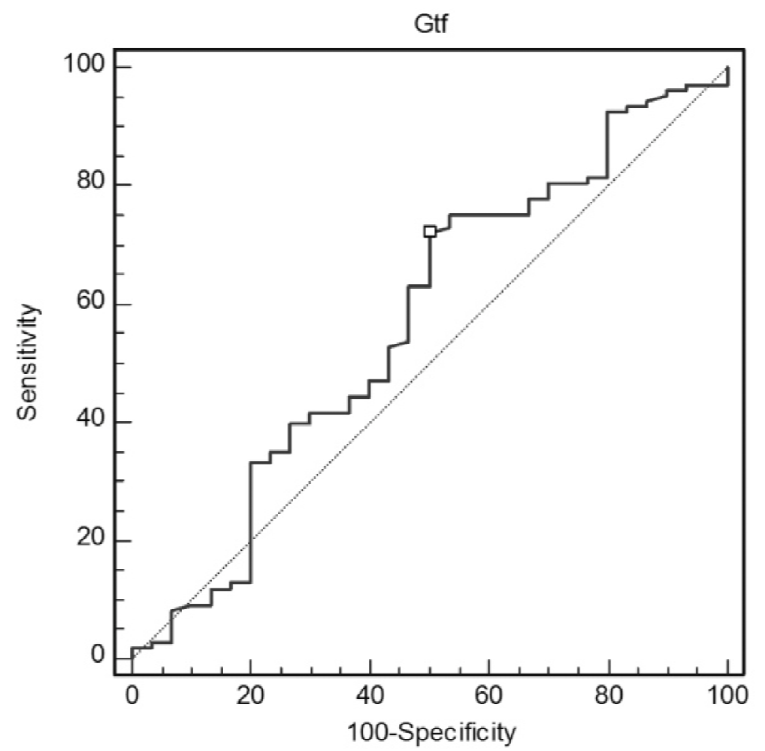

Gambar 1. Cut Off Point GTF

Cut Off Point terhadap kadar enzim GTF diperoleh bahwa sensititas 72,22 persen dengan $95 \%$ konfiden interval $62,8-80,4$ dan spesifisitas 50 persen dengan $95 \%$ konfiden interval $31,3-68,7$ serta nilai $p=0,244$. Hasil cut Off Point tersebut diperoleh bahwa $\leq 5,427$ $\mathrm{ng} / \mathrm{ml}$ mengartikan berisiko terjadi karies gigi. Sedangkan Cut Off Point terhadap kadar MUC7 diperoleh hasil bahwa sensitifitas 54,63 persen.

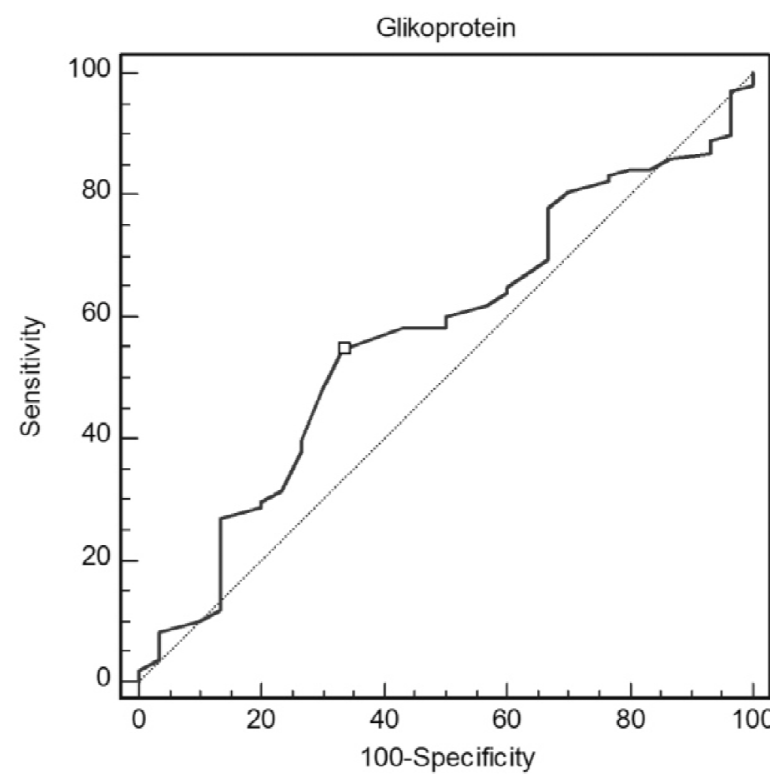

Gambar 2 Cut Off Point MUC7

dengan 95\% kkonfiden interval 44,8 - 64,2 dan spesifisitas 66,67 persen dengan $95 \%$ konfiden interval $47,2-82,7$ serta nilai $p=0,249$. Nilai Cut Off Point yang diperoleh terhadap kadar MUC7 $\leq 604,02 \mathrm{ng} / \mathrm{ml}$ berarti bila kadar MUC7 berada dibawa kadar tersebut mempunyai risiko terhadap terjadinya karies gigi. (gambar 2))

Analisis pengaruh simultan kadar MUC7 dan kadar GTF terhadap kejadian karies gigi digunakan analisis regresi logistic ganda. Kemaknaan hasil uji berdasarkan nilai $p<0,05$, terlihat pada Tabel berikut;

\begin{tabular}{|c|c|c|c|c|c|}
\hline Variabel & & Koef B & S.E (B) & Nilai $p$ & POR $\quad($ IK 95\% C) \\
\hline Langkah & 1 kat_MUC7 1 & 0,740 & 0,446 & 0,097 & $2,096(1,007 \quad 4,362)$ \\
\hline & Kat_GTF 1 & 0,849 & 0,437 & 0,052 & $2,337(1,1394,797)$ \\
\hline & konstanta & $-0,243$ & 0,796 & 0,760 & 0,784 \\
\hline \multirow[t]{3}{*}{ Langka 2} & kat_MUC7 1 & 0,735 & 0,444 & $0,049^{*}$ & $2,085(1,0054,326)$ \\
\hline & kat_gtf 1 & 0,821 & 0,434 & $0,029^{*}$ & $2,273(1,114 \quad 4,639)$ \\
\hline & konstanta & 0,454 & 0,346 & 0,199 & 1,575 \\
\hline
\end{tabular}

a.Variable(s) entered on step 1: kat_MUC71, kat_gtf1 POR : Prevalen Odds Ratio

Tabel 5 tersebut memperlihatkan bahwa hasil uji regresi logistik ganda diperoleh hasil MUC7 dan GTF tersebut berhubungan dengan terjadinya karies gigi. Selain itu juga ternyata bahwa apabila kadar MUC7 $\leq$ $604,02 \mathrm{ng} / \mathrm{ml}$, maka anak usia 12-13 tahun di SPMN2 pengalengan mempunyai risiko untuk terjadinya karies gigi adalah 2,085 kali bila dibandingkan dengan kadar gliko $>604,02$. Sedangkan kadar GTF $\leq 5,247$ akan mempunyai risiko untuk terjadinya karies gigi sebesar 2,273 kali bila dibandingkan dengan kadar $\mathrm{Gtf}>5,247$.

Hasil penelitian diperoleh indeks DMF-T sebesar 3,007. berada dalam kategori moderat untuk usia 12 tahun sesuai dengan world map of dental caries yang di kemukakan oleh Petersen.31 Apabila dibandingkan dengan hasil riskesdas Jawa Barat untuk usia 12 tahun, maka hasil tersebut masih lebih tinggi. DMF-T Jawa Barat hasil riskesdas tahun 2007 sebesar 2,67 untuk usia 12 tahun. Begitu pula dengan DMFT usia 12 tahun Bangka Belitung DMFTnya masih lebih rendah yaitu- 
2,47. Perbandingan antara indeks DMF-T hasil penelitian dengan nasional, maka sangat jauh di atas nilai nasional untuk usia 12 tahun yaitu 0,91. Selain itu, terbukti masih lebih rendah dibandingkan hasil penelitian Aripin D (2010), dengan nilai DMF-T sebesar 4,22. Begitu pula hasil pemeriksaan dilakukan pada 2.378 anak 12 tahun di tenggara Brazil diperoleh dari semua sampel DMFT adalah 3,02, sedikit dibawah Tenggara Brazil.

Hasil penelitian yang dilakukan di Venda, provinsi bagian utara Afrika Selatan juga memperlihatkan adanya perbedaan yang signifikan DMFT (sd) pada anak usia 12 dan usia 15 tahun. Sedangkan hasil diperoleh peneliti tidak ditemukan hubungan antara usia 12 - 13 tahun dengan kejadian karies gigi dengan $p=0,680$.

Beberapa faktor yang menyebabkan cukup rendahnya indeks DMF-T pada anak karyawan PTPN VIII Pangalengan usia 12-13 tahun bahwa PTPN VIII merupakan perkebunan penghasil utamanya adalah teh. Masyarakat perkebunan PTPN VIII, dan sebagian besar masyarakat Indonesia minuman sehari-harinya adalah teh. Teh sangat bermanfaat untuk kesehatan gigi.

Minuman teh mempengaruhi jumlah bakteri saliva. Tingkat pengurangan Streptokokus Mutan bisa mencapai 60 sampai 99,9\% dan 91 sampai $98 \%$ untuk laktobasilus. Begitu pula hasil penelitian di Iran bahwa teh hijau dan teh hitam menimbulkan efek anti aktifitas Sterptokokus mutan secara in vitro, karena teh hijau dan hitam Iran memiliki efek antibakteri pada konsentrasi 100 sampai $400 \mathrm{mg} / \mathrm{ml}$. Konsentrasi hambat minimum teh hijau dan hitam adalah 150 dan $50 \mathrm{mg} / \mathrm{ml}$. Diketahui bahwa teh mengandung zat, seperti polifenol, terbukti memiliki sifat antibakteri terhadap bakteri kariogenik, terutama Streptokokus mutan. Telah juga diteliti pada teh oolong hijau dan teh hitam bahwa polifenol tehnya berefek anti karies melalui anti mikroba, ester galloyl dari epikatekin, epigallocatechin dan gallocatechin memperlihatkan peningkatan aktivitas antibakteri.

Selain itu teh juga mengandung Fluor yang sifatnya lebih menguatkan gigi terhadap demineralisasi karena asam plak. Fluor merupakan salah satu cara untuk mencegah terjadinya karies gigi. Lebih dari 60 tahun fluor telah digunakan untuk mencegah terjadinya karies melalui fluoridasi air minum, serta menunjukkan bahwa fluoridasi air menurun prevalensi karies pada anak dan orang dewasa. Teh hijau dan kopi juga mengandung berbagai jumlah fluoride, begitu pula teh polong, maupun teh hitam. Kandungan fluor dalam teh yang dilakukan oleh beberapa peneliti juga bermacammacam. Hasil yang dilakukan oleh Belde C (2011) mendapatkan kandungan fluoride dalam teh hijau organik dan non-organik masing-masing berkisar antara 0,08-0,47 mg F-/g daun teh dan 0,10-0,37 mg F/ teh g daun teh. Teh Brazil yang terbuat dari Camellia sinensis, beberapa teh melebihi batas asupan harian untuk anak-anak. Teh hitam Brazil, menunjukkan nilai lebih tinggi nilai dari yang telah ditentukan yaitu 0,07 $\mathrm{mg} \mathrm{F} / \mathrm{kg} /$ hari sebagai batas atas asupan fluorida berkaitan dengan fluorosis gigi, sedangkan fluoride antara 0,08-0,40 mg F/bag.

Oleh karena itu Yuwano (2005) mengatakan bahwa teh hitam dan teh hijau mempunyai kontribusi penting terhadap total asupan fluor setiap hari. Namun, untuk anak-anak, karena teh hitam memiliki kandungan fluoride yang tinggi, sehingga berresiko fluorosis gigi, maka anak anak harus dihindari mengkonsumsi the hitam.

Hasil penelitian diperoleh bahwa korelasi antara karies dengan Glukosil- transferase(GTF) dan glikoprotein (MUC7) melalui uji Mann Whitney tidak terbukti ada hubungan yang signifikan dengan terjadinya karies gigi. Begitu pula melalui analisis korelasi Point Biserial juga tidak terbukti adanya korelasi yang signifikan antara karies dengan GTF dan MuC7.

Kadar MUC7 $\leq 604,02 \mathrm{ng} / \mathrm{ml}$ mempunyai risiko untuk terjadinya karies gigi adalah 2,085 kali bila dibandingkan dengan kadar MUC7 >604,02.ng/ml. Sedangkan kadar Gtf $\leq 5,247 \mathrm{ng} / \mathrm{ml}$ mempunyai risiko untuk terjadinya karies gigi sebesar 2,273 kali bila dibandingkan dengan kadar Gtf $>5,247 \mathrm{ng} / \mathrm{ml}$. Pada kurva ROC diperoleh cut off point untuk GTF dan glikoprotein, dan hasil multivariabel dengan regresi logistik nampak kedua variabel tersebut terdapat hubungan yang signifikan dengan karies.

Tanpa atau penurunan kadar musin, mengakibatkan mukosa mulut dan permukaan gigi akan menjadi rentan terhadap infeksi, peradangan dan mekanikal serta meningkatkan kolonisasi periopatogen, menimbulkan penyakit periodontal. Jumlah glikoprotein yang berada dalam saliva, menentukan seseorang akan menjadi rawan karies. Ketika diterapkan pada anak-anak, tes ini dapat digunakan untuk memprediksi perkembangan karies, dan digunakan untuk saran pencegahan karies. MUC7 dapat melekatkan bakteri mulut seperti Streptokokus mutan dan memperbesar kolonisasi di permukaan gigi. Streptokokus mutan sebagai bakteri etiologi karies gigi, maka MUC7 dapat di duga berkorelasi dengan terjadinya karies gigi. Hasil penelitian yang dilaksanakan oleh Radlińska J. B, Pol J, Szmidt M, Bińczak-Kuleta A. (2012) bahwa tidak menunjukkan korelasi antara MUC7 dengan karies dan kebersihan mulut siswa. MUC7 bukan sebagai prediktor karies yang baik bagi siswa Polandia. Dengan demikian hasil tersebut sama dengan diperoleh peneliti. Akan tetapi peneliti memperoleh hasil bahwa rendahnya kadar MUC7 akan meningkatkan terjadinya karies gigi.

Kannan I, Arun Kumar C, Sambandam C. K, Jayalakshmi M, Premavathy r. K, Shantha S (2013) menyatakan bahwa prasyarat penting terbentuk karies gigi adalah kemampuan streptokokus mutan membentuk biofilm (plak) yang dimediasi enzim glukosiltransferase (GTF). Enzim ini mendasari virulensi S. mutans menimbulkan karies gigi. Begitu pula halnya Yousefi B, Ghaderi S, Rezapoor-Lactooyi A, Amiri N, Verdi J, and Shoae-Hassani A (2012) menyatakan bahwa Streptokokus merupakan komponen penting biofilm (plak gigi), dan memiliki relevansi langsung dengan 
patogenisitas plak serta bisa hidup dalam lingkungan $\mathrm{pH}$ rendah. Mekanisme utama Streptokokus mutan produksi glukan dari sukrosa melalui glucosyltransferases (GTF) yang merupakan faktor virulensi penting terkait patogenesis Streptokokus mutan.

Vacca Smith A.M, Scott-Anne K. M, Whelehan M. T, Berkowitz R. J, Feng C, Bowen W. H (2007) melakukan penelitian memperoleh yang yang sama yaitu tidak terdapat korelasi antara aktivitas enzim GTF dengan nilai DMFS atau pengalaman karies. Akan tetapi terjadi korelasi yang sangat signifikan antara jumlah streptokokus mutans dengan karies. Streptokokus mutan (MS), adalah agen penyebab utama karies gigi. Sintesis glukan dari sukrosa melalui aksi enzimatik glucosyltransferases (GTF). Struktur Isomer sukrosa (yaitu, disakarida yang terdiri dari glukosa dan fruktosa) tidak akan berfungsi sebagai substrat untuk GTases Streptokokus mutan, melainkan sebagai sumber energi Streptokokus mutan. Oligomer glukosa mengandung $\alpha-1,6$ dan/atau $\alpha-1,4$ linkages sebagai penghambat sintesis glukan dari sukrosa oleh Streptokokus mutan, meskipun oligomer ini dihidrolisis oleh Streptpkokus mutan untuk menghasilkan asam.

\section{SIMPULAN}

1. Tingginya kadar MUC7 bukan faktor risiko terjadinya karies gigi pada anak usia 12-13 tahun

2. Tingginya kadar glukosiltransferase bukan faktor risiko terjadinya karies gigi pada anak usia $12-13$ tahun

3. terbukti bahwa terdapat hubungan antara kadar MUC7, dengan kadar enzim glukosiltransferase (GTF) dalam saliva dan saling berkaitan dengan karies gigi.

\section{Simpulan khusus}

1). Hasil penelitian ini diperoleh bahwa kadar MUC7 $\leq 604,02 \mathrm{ng} / \mathrm{ml}$ mempunyai risiko karies sebesar 2.085 kalinya bila dibandingkan MUC7 > 604,02 $\mathrm{ng} / \mathrm{ml}$.

2).Hasil penelitian justru ditemukan kadar glukosiltransferase $\leq 5,247 \mathrm{ng} / \mathrm{ml}$ mempunyai risiko sebesar 2,273 kali bila dibandingkan kadar GTF > 5,247 $\mathrm{ng} / \mathrm{ml}$.

\section{DAFTAR PUSTAKA}

Roberson T.M and Thomas F. Lundeen. Cariology: The Lesion, Etiology, Prevention, and Control. In Sturdevant's Art \& Science of Operative Dentistry. 4th ed. Editor Theodere M. Roberson, Harald O. Heymann, and Edward J. Swift, Jr. St Louis. Mosby Inc. 2002.

Samaranayake L. P. Essential Microbiology for Dentistry. 2nd ed. Churchill Livingstone. Harcourt publishers Limited. Hongkong. 2002

James D. Bader J. D, Rozier G, Harris R, Lohr H. R, Dental Caries Prevention: The Physician's Role in Child Oral Health Systematic Evidence Review. http://www.ahra.gov/downloads Lpub/prevent/pdfser/dentser.pdf. di unduh tanggal 11/9/2009 jam 11.37 AM.

André V. Ritter. Talking with Patients Dental Caries. journal of esthetic and res torative dentistry. $2004 \mathrm{BCDecker}$ Inc.

Newburn E. Cariology. 3rd. Quintessence Publishing Co. Inc. Chicago. P 115-119. 1989

Reich E, Lussi A and Newbrun E. Caries-risk assessment. International
Dental Journal (1999) 49, 15-26. 1999 FDI/World Dental Press.0020-6539/99/01015-12.

Harris R, Nicoll1 A. D, Adair P. M and Pine C. M Risk factors for dental caries in young children: a systematic review of the literature. Community Dental Health (2004) 21 (Supplement), 71-85. (C) BASCD 2004. Diunduh tanggal 13-10-2009 jam 9.07 PM.

Bardow A, Lagerlof F, Nauntofte B, and Tenovuo J. The role of saliva (in dental caries the disease and its clinical management edited by Olefayerkov and Edwina Kidd) 2sd ed. Blackwell munsgaard Ltd. 2008

Pedersen A.M.L, Saliva. Zendium. 2007. http://www.zendium.dk/ Files/zendium.dk/material/publikationer/saliva.pdf. diunduh tgl 14-5-2012 jam 5.13 PM.

Wikipedia. Saliva. http://en.wikipedia.org/wiki/Saliva. di unduh tgl 6 -6-2012. Jam 9.04PM

Liljemark F. W, Bloomquist G. C. Normal microbial flora of the human body. In oral microbiology and immunology. Michael $G$. Newman, Russell Nisengard,. W.B. Saunders Company. Phidelphia. 1988. P141,142

Oliveira R. T. R. M.. Inhibition of bacterial adherence to saliva coated through plant lectins. Journal of Oral Science, Vol 49, no 2, 141145, 2007.

Gillece-Castro BL Prakobphol A, Burlingame AL, Leffler H, Fisher SJ. Structure and Bacterial Receptor Activity of a Human Salivary Proline-rich Glycoprotein. the journal of holoclcal chemlstry. Vol. 266, No. 26, Issue of September 15, pp. 17358-17368, 1991

Cephas D. K. Comparative Analysis of Salivary Bacterial Microbiome Diversity in Edentulous Infants and Their Mothers or Primary Care Givers Using Pyrosequencing. http://www.plosone.org/ article/info\%3Adoi\%2F10. 1371\%2F journal.pone.0023503 jam 7.48 PM 5/30/2013

Loesche W. J, Rowan J, Straffon L. H. and Loos P. J. Association of Streptococcus mutans with Human Dental Decay. INFECTION AND IMMUNITY, June 1975. p. 1252-1260. Vol. 11, No. 6

Frank A. Scannapieco, Saliva-Bacterium Interactions in Oral Microbial Ecology. Critical Reviews in Oral Biology \& Medicine. 5(3\&4):203248. 1994

Sivapathasundharam B and Raghu AR. Dental Caries. (in Shafer's textbook of Oral Pathology editors R Rajendran and B Sivapathasundharam ) 5 th ed. Reed Elsevier India Private Limited. New Delhi . 2007

Kindblom C Davies JR, Herzberg M. C, Svensäter G, Wickström C. Salivary proteins promote proteolytic activity in Streptococcus mitis biovar 2 and Streptococcus mutans. http://dspace.mah.se/handle/2043/14937

Bosch J. A, De Geus E. C. I, Veerman E. C. I, Hoogstraten J, , and Nieuw Amerongen A. V

Innate Secretory Immunity in Response to Laboratory Stressors That Evoke Distinct Patterns of Cardiac Autonomic Activity. Psychosomatic Medicine 65:245-258 (2003).

Denny P. C. and Denny P. A. Dental caries risk assessment in Salivary Diagnostics edited by David T Wong. Wiley-Blackwell. A John Wiley \& son Ltd, Publication. Singapure. 2008.

Nauntofe. B, J.O Tenovuo and F. lagerlöf. Secretion and composition of Saliva. In Dental Caries The disease and its clinical management. Edited by Ole Fejerskov and Edwina A.M. Kidd. Blackwell Munksgaard. Copenhagen. Denmark. 2003

F'abi'an. K. T and P'al Fej'erdy, P'eter Csermely. Saliva in health and disease, chemical biology of. WILEY ENCYCLOPEDIA OF CHEMICAL BIOLOGY 2007, John Wiley \& Sons, Inc

Pol J. Association of the polymorphism of MUC7 gene encoding the low-molecular-weight mucin mg2 with susceptibility to caries. Annales aca demiae medicae stetinensis roczniki pomorskiej akademii medycznej w szczecinie 2011, 57, 2, 85-91

Karlsson G. N and Thomsson A. K. Salivary MUC7 is a major carrier of blood group I type O-linked oligosaccharides serving as the scaffold for sialyl Lewis $x$. Glycobiology vol. 19 no. 3 pp. 288-300, 2009.

Li S and Bobek A. L. Functional Analysis of Human MUC7 Mucin Gene 5_-Flanking Region in Lung Epithelial Cells. Am J Respir Cell Mol Biol Vol 35. pp 593-601, 2006.

U. Lendenmann, J. Grogan and F.G. Oppenheim. Saliva and Dental Pellicle-A Review. 01 Adv. Dent. Res. 2000; 14; 22

Ramseier C. A, Morelli T, Kinney J. S, Dobois M, Rayburn L, and Giannobile W. Periodontal Disease. . In Salivary Diagnostics edited by David T Wong. Wiley-Blackwell. A John Wiley \& son Ltd, Publication. Singapure. P 159. 2008. 
Aoki H, ImamuraY, Ouryouji K, Miyazawa H, and Wang P. L. Genetic Polymorphism of the saliva mucin gen MUC7 in severe caries in Japanese pediatric patient. Pediatric Dental Journal. 20(2): 152157. 2010.

Radlińska J. B, Justyna Pol, Szmidt M, Kuleta A. B. The influence of polymorphism of the MUC7 gene on the teeth and dental hygiene of students at a faculty of dentistry in Poland. Postepy Hig Med Dosw (online), 2012; 66: 204-209

Lehner T. Immunology of oral diseases. third ed. Blackwell Scientific Publocation. Oxford. 1992

World Health Organization Poul Erik Petersen. World map on dental caries 12 years. WHO. 2003

Badan Penelitian dan Pengembangan Kesehatan Departemen Kesehatan, Republik Indonesia. Riset Kesehatan Dasar (RISKESDAS) 2007 LAPORAN Provinsi Bangka Belitung. 2008.

Baehni P.C and B. Guggenheim. potential of diagnostic microbiology for treatment and prognosis of dental caries and periodontal diseases. Crit Rev Oral Biol Med. 7(3):259-277 (1996).

Aripin D. Hubungan Kadar Protein SCD14, Jumlah Streptococcus Mutans dalam saliva dan kejadian Karies pada anak karyawan PTPN VIII Pangalengan usia 12-15 tahun. Disertasi. Program Pascasarjana Universitas Padjadjaran bandung 2010.

Cypriano S, Hoffmann R. H. S, de Sousa M. R, Wada R. S. DENTAL CARIES EXPERIENCE IN 12-YEAR-OLD SCHOOLCHILDREN IN SOUTHEASTERN BRAZIL. J Appl Oral Sci. 2008;16(4):286-92.

Bajomo A. S, Rudolph M. J and Ogunbodede E. O. DENTAL CARIES IN SIX, 12 AND 15 YEAR OLD VENDA CHILDREN IN SOUTH AFRICA. East African Medical Journal Vol. 81 No. 5 May 2004

Abd Allah A. A, Ibrahium M. I and Al-atrouny A.M. Effect of Black Tea on Some Cariogenic Bacteria. World Applied Sciences Journal 12 (4): 552-558, 2011. ISSN 1818-4952

Naderi N. J, Niakan M, Kharazi Fard M.J, Zardi S. Antibacterial Activity of Iranian Green and Black Tea on Streptococcus Mutans : An In Vitro Study. Journal of Dentistry, Tehran University of Medical Sciences, Tehran, Iran (2011; Vol.8, No.2)

Sharma VK, Bhattacharya A, Kumar A and Sharma HK. Health Benefits of Tea Consumption. Tropical Journal of Pharmaceutical Research, September 2007; 6 (3): 785-792

Kshitiz P, Shipra Z, Rani S, Jayanti S. Anti Cariogenic Effect of Polyphenol Plant Products a Review. International Journal of Research in Ayurveda \& Pharmacy, 2(3), 2011 736-742.

Zero D. T, Fontana M, Martínez-Mier E. A, Ferreira-Zandoná A, Ando M, González-Cabezas $C$, et al. The biology, prevention, diagnosis and treatment of dental caries Scientific advances in the United States. J Am Dent Assoc 2009; 140;25S-34S

Belde C. Comparison of Polyphenols and Fluoride content in Commercial Brands of Organic and Nonorganic Green Tea. The Graduate School University of Wisconsin-Stout.Decemeber, American Psychological Associa tion, 6th edition.2011.

Hayacibara M. F, Queiroz C. S, Tabchoury C. P. M and Cury J. A. Fluoride and aluminum in teas and tea-based beverages. Rev Saúde Pública 2004;38(1):100-5.

Yuwono M. Determination of fluoride in black, green and herbal teas by ionselective electrode using a standard-addition method. Maj. Ked. Gigi. (Dent. J.), Vol. 38. No. 2 April-Juni 2005: 91-95

Becker T, Levin L, Shochat T, Einy S. How Much Does the DMFT Index Underestimate the Need for Restorative Care? May 2007 Journal of Dental Education. Volume 71, Number 5.

Bayat-Movahed S, Samadzadeh H, Ziyarati L, Memary N, Khosravi R, Sadr-Eshkevari PS. Oral health of Iranian children in 2004: a national pathfinder survey of dental caries and treatment needs. Eastern Mediterranean Health Journal. Vol. 17 No. 3 2011. $243-$ 249

Loesche W. J. Role of Streptococcus mutans in Human Dental Decay. microbiological reviews, Dec. 1986, p. 353-380. 1986, American Society for Microbiology. Vol. 50, No. 4.

El-Nadeef M. A, Al Hussani E, Hassab H, Arab I. A. National survey of the oral health of 12- and 15-year-old schoolchildren in the United Arab Emirates. Eastern Mediterranean Health Journal, Vol. 15, No. 4, 2009. 993-1004

Radlińska J. B, Pol J, Szmidt M, Bińczak-Kuleta A. The influence of polymorphism of the MUC7 gene on the teeth and dental hygiene of students at a faculty of dentistry in Poland. Postepy Hig Med Dosw (online), 2012; 66: 204-209. e-ISSN 1732-2693

Kannan I, Arun Kumar C, Sambandam C. K, Jayalakshmi M, Premavathy r. K, Shantha S. Quinic acid derivatives as inhibitor of glucosyltransferase SI, a virulence factor of streptococcus mutans in the pathogenesis of dental caries. IJPRD, 2013; vol 4(11): January-2013 (037-043).

Yousefi B, Ghaderi S, Rezapoor-Lactooyi A, Amiri N, Verdi J, and ShoaeHassani A. Hydroxy decenoic acid down regulates gtfB and gtfC expression and prevents Streptococcus mutans adherence to the cell surfaces. Annals of Clinical Microbiology and Antimicrobials 2012, 11:21

Vacca Smith A.M, Scott-Anne K. M, Whelehan M. T, Berkowitz R. J, Feng C, Bowen W. H. Salivary Glucosyltransferase B as a Possible Markerfor Caries Activity. Caries Res 2007;41:445-450.

Hamada S. Role of sweeteners in the etiology and prevention of dental caries. Pure Appl. Chem. Vol. 74, No. 7, pp. 1293-1300, 2002. 